\title{
Beyond Obstacles: Toward Justice for Victims of Sexual Violence in Hungary. A Literature Review
}

TRAUMA, VIOLENCE, \& ABUSE I-15

(c) The Author(s) 2021

Article reuse guidelines:

sagepub.com/journals-permissions DOI: $10.1 \mid 177 / 15248380211027990$ journals.sagepub.com/home/tva

@SAGE

\author{
Katalin Parti ' ${ }^{\mathbb{D}}$, Robin A. Robinson ${ }^{2,3}$, David Kohlmann ${ }^{4}$, \\ Enikö Virágh ${ }^{4}$, and Dóra Varga-Sabján ${ }^{5}$
}

\begin{abstract}
Alarmed by research that reveals Hungary as having one of the lowest reporting rates in cases of sexual violence in Europe, this article provides an overview of the research that explains why, historically, sexual violence has been and continues to be underreported all over the globe, from law enforcement and criminal justice perspective. Furthermore, we describe the unique circumstances that might influence Hungarian victims of sexual violence to make formal reports. Among other possible factors, we discuss rape myth acceptance, victim blaming, feminist activism, institutional betrayal, and media representations of rape. In an effort to provide insight into Hungarian gender politics, this article raises salient theoretical works on gender ideology and gender policy in contemporary Hungary. This article concludes with a discussion on what implications such research in Hungary may have on a global understanding of sexual violence reporting.
\end{abstract}

\section{Keywords}

Hungarian feminism, rape culture, rape myth acceptance, gender politics, gender policy

\section{Introduction: The underreporting of rape}

Victims of rape and other forms of sexual violence can only access justice and formal support if they (or a third party) file an official report and if they partake in those legal processes which could lead to justice being served. Reporting rape and other sexual violence may protect a victim and perhaps prevent further victimization by the perpetrator, as well as provide a resolution through criminal justice procedures and remedies. Research reveals a complex interplay of actors and factors that result in victims remaining silent and consequently perpetrators remaining unpunished. Although rape statistics and research results are not fully commensurable because of the diversity of definitions and measurement units they utilize, we attempt to draw a rough picture of Hungary's place in the propensity of reporting rape. For similar reasons, in this study, we utilize a broad definition of sexual violence that encompasses sexual assault as well as rape.

Underreporting of rape incidents is a universal pattern across the globe, with United States-based surveys typically showing an alarming 10\%-16\% reporting rate (Spohn et al., 2017; Wolitzky-Taylor et al., 2011). Among countries with the lowest rate of rape reports, Hungary stands out with a reporting rate of only $8 \%$ (Virág, 2004), and, in a recent study, the lowest reporting rate among 28 European countries, with only 2.1 reports per 100,000 people (Lovett \& Kelly, 2009). Some estimates go even further: Hungarian nongovernmental organization (NGO) Nõk a Nõkért Együtt az Erõszak Ellena women's rights organization-claims that only $0.24 \%$ of all rape incidents are officially registered (Wirth \& Winkler, 2015). One obvious explanation for the lowest rate of rape reports in the region would be an extremely low number of rape incidents, but data show a close-to-average rate of sexual violence against women in Hungary. According to a Europewide survey (European Union [EU] Agency for Fundamental Rights, 2014), 22\% of women aged 15 or older have experienced physical and/or sexual violence by a current or former partner, and $22 \%$ by a nonpartner, making the victim rate $33 \%$ of women in general. These rates are $21 \%$ (victimized by partner), $14 \%$ (victimized by nonpartner), and $28 \%$ (victimized by anybody) in Hungary (EU Agency for Fundamental Rights, 2014). Even if this Europe-wide study asked about

\footnotetext{
'Department of Sociology, Virginia Polytechnic Institute and State University, Blacksburg, VA, USA

${ }^{2}$ Department of Sociology, University of Massachusetts Dartmouth, MA, USA

${ }^{3}$ Women's Studies Research Center, Brandeis University, MA, USA

${ }^{4}$ Eötvös Lóránt University, Budapest, Hungary

${ }^{5}$ Pécsi Tudományegyetem, Pécs, Hungary

Corresponding Author:

Katalin Parti, Department of Sociology, Virginia Polytechnic Institute and State University, 512 McBryde, 225 Stanger St., Blacksburg, VA 2406I, USA.

Email: kparti@vt.edu
} 
victimization of sexual and physical violence, the compared rates of reporting per country indicate that Hungary stands out as having the lowest reporting of intimate violence. The characteristics of reported incidents are similar to those in other countries as two thirds of sexual violence is committed at home, by a current or a previous intimate partner, a family member, or an acquaintance (Parti et al., 2016; Virág, 2004). These patterns repeat in recent studies from the Hungarian National Institute of Criminology, which has estimated similar rates: In $83 \%$ of the cases, the victim and the offender knew each other, in $60 \%$ of the cases, the act was committed at the home of the victim or the perpetrator, while only $22 \%$ was perpetrated on the street, $2 \%$ in workplaces, and $14.8 \%$ in other places (Parti et al., 2017b).

This article aims to reveal what the literature has found about the reasons why rape is so vastly underreported in Hungary. After reviewing universal patterns and explanations of the underreporting of sexual violence such as rape culture, rape and denial, institutional betrayal, factors influencing reporting, rape myth acceptance (RMA), and its role in underreporting, we discuss the Hungarian case. We provide a historic review of feminism in the country, the recent cases emerging along with the global \#MeToo movement, the level of trust in authorities and how it influences rape reporting, and the role of current legislation that shapes gender and body politics.

Before delving into the literature, it is necessary to state that, as of now, there are only a handful of scientific research studies available on victimization and the causes of underreporting sexual violence in Hungary. The lack of such material can be attributed to a general scarcity of funding within academic research (Tarlea, 2017) and a political climate that does not allow for research that may call into question the current political agenda or the sacrosanctity of family (Zimanyi, 2020). The political concept of the family will be further discussed in this article.

\section{Rape Culture}

The term "rape culture" encompasses the normative social context and practices that create an enabling environment for rape. The concept recognizes certain traditions and cultural norms as elements that contribute to a higher proclivity toward and passive acceptance of rape. To be more precise, it points to patriarchal notions of gender (Brownmiller, 1975) — which continuously reproduce rape culture through male peer support-and to public discourse as mechanisms that maintain a rape-supportive social environment (Hayes et al., 2016). At the core of rape culture are rape myths and victim blaming as well as gender-related norms and practices. Rape culture is created and supported through society's definition and control of women's sexuality, defining rape as a crime of sex versus power, upholding traditional gender norms, and creating an environment where rape myths are continually accepted (Hayes et al., 2013). Rape culture comes to life in an early qualitative study of Burgess and Holmstrom (1974), where a rape victim asserts: "My father always said whatever a man did to a woman, she provoked it" (Rape victim interview; Burgess and Holmstrom, 1974, p. 983). Nevertheless, rape culture is not solely an individual's justification, but rather a shift in focus from the individual level to the societal and an emphasis on that rape is a phenomenon both stemming from personal behavior and beliefs and rooted in the institutionalized norms and practices of our culture. It must be addressed in a larger context of sexual violence.

Herman (2015) describes how human-caused traumatic events such as sexual violence demand both concealment and disclosure on the individual and societal level. The interest of perpetrators is to pretend as if nothing has happened and to maintain secrecy; in order to heal however, victims and witnesses must break the silence. Taking sides with perpetrators, especially if they have power, is always more appealing for bystanders: Perpetrators only demand inaction, whereas being on the side of the victim requires empathy and sharing the pain. To promote public amnesia, perpetrators need to silence victims, to keep them unreliable, invisible. Obversely, victims who are trying to find justice often fall into denial, disrespect, and disbelief. Herman illustrates these tendencies by describing three historic periods of trauma research: (1) the studies on hysteria and the history of psychoanalysis (wherein Freud, despite having established a connection between sexual trauma and abuse in his early writings, later abandoned this theory and instead represented the stories of sexual abuse he encountered as the fantasies and hidden desires of women); (2) the research on combat neurosis after World War I and World War II (WWII), the long-lasting struggle of veterans for society's acknowledgment of their suffering, and the first inclusion of post-traumatic stress disorder (PTSD) in the Diagnostic Manual of the American Psychiatric Association in 1980; and (3) the research on sexual violence and the struggle of the women's rights movement to define sexual assaults as reprehensible violence instead of as a provoked or secretly desired action. This later research also revealed how statistically commonplace sexual abuse is for women and children: Every fourth woman has been raped and every third experienced sexual abuse as a child according to an epidemiological survey conducted by Russell and Bolen (2000), though legal and lay definitions of these abuses vary. These historical examples show a general sociocultural reluctance to believe and address the effects of sexual violence in society. Furthermore, they illustrate the struggles victims face in speaking out about their experiences, pursuing justice and integrating their traumagenic experience into everyday life.

\section{Institutional Betrayal}

Rape culture is reflected in the institutionalized norms and practices of our societies, with institutional betrayal playing a large role. "Institutional betrayal is a description of individual experiences of violations of trust and dependency perpetrated against any member of an institution in a way that does not necessarily arise from an individual's less-privileged identity" (C. P. Smith \& Freyd, 2014, p. 577). Institutional betrayal 
refers partly to the violence which happens within an institution, that is, where both the victim and perpetrator are members of the same community (the perpetrator usually being higher in the institutional hierarchy), for example, the military, childcare system, schools, workplaces, and religious organizations. But it also refers to when the institutions to which victims turn (legal, medical, and mental health systems) let the victim down and violate the trust. These institutions are often gatekeepers in the process, meaning the victim has nowhere else to turn if they want, for example, to report a sexual assault or rape. Interestingly, the more severe the sexual assault, the more likely the victim will be to receive negative reactions from these supportproviding institutions (Ullmann et al., 2007).

According to the findings of C. P. Smith and Freyd (2013), "consistent with betrayal trauma theory, sexually assaulted women who also experienced institutional betrayal experienced higher levels of several posttraumatic symptoms" ( $p$. 122). The reaction of the community has an enormous effect on the victim's capacity to deal with the traumatic experience, whether this reaction is positive or negative: Acceptance and rehabilitation are both necessary to reestablish the faith in justice and a rational world (Herman, 2015; Ullmann, 1999). Negative social reactions such as disbelief, different treatment, distraction, taking control over the victim's decisions, egocentric responses, blaming, anger, or lack of support lead to consequences defined as "second injury" by Symonds ([1980] 2010; cited by Ullmann et al., 2007) and which are experienced by victims relatively often. Nondisclosure and second injuries may lead to social isolation, avoidance-coping, and characterological self-blame (and thus to depression, anxiety, and PTSD), while supportive reactions have positive or at least neutral effects on recovery (Ullmann et al., 2007).

\section{Factors Influencing Reporting and Causes of Not Reporting}

Reporting rape is far from a straightforward decision for victims. This is illustrated by the multitude of situational factors that have been identified as influences on the likelihood of victims filing an official report. Research shows that victims raped by an acquaintance are less likely to report the incident (Heath et al., 2013; McGregor et al., 2000) but are more likely to report, if the perpetrator is a stranger (Paul et al., 2014; Suzuki \& Bonner, 2017; Wolitzky-Taylor et al., 2011). The likelihood of reporting is higher if the sexual assault results in severe physical injury or the fear of serious injury, when the perpetrator uses physical force or a weapon, or when the victim suffers from serious psychological symptoms following the assault (Bachmann, 1998; du Mont et al., 2003; Paul et al., 2014; Russell \& Bolen, 2000; Wolitzky-Taylor et al., 2011). Victims are more likely to report if they were not under the influence of substances during the incident (Fisher et al., 2003; Kilpatrick et al., 2007; Wolitzky-Taylor et al., 2011) and in cases where they had clearer memories of the event (Kilpatrick et al., 2007). As for the personal characteristics of victims, those who trust the police and desire services are more likely to report (Moore \& Baker, 2018), but those who have a history of sexual victimization are less likely to turn to the authorities or to support organizations (Fisher et al., 2003; Wolitzky et al., 2011). Victims of sexual violence normally look for tangible aid and informational support when they disclose their experiences to physicians and/or the police, but as they often face negative reactions from these support providers, they find them unhelpful (Ullmann, 1999). Demographic variables, such as age, education level, marital status, racelethnicity, and socioeconomic status, have not been consistently proven to be related to the likelihood of reporting rape.

The most important reasons victims give for not reporting their rape are not wanting other people to find out about the incident typically out of fear of negative reactions such as blame or stigmatization (Heath et al., 2013; Kilpatrick et al., 1992; Parti et al., 2016; Wolitzky-Taylor et al., 2011), fear of reprisal (Allen, 2007; Felson \& Pare, 2005; Wolitzky-Taylor et al., 2011), and fear of disbelief or bad treatment by the authorities (Allen, 2007; Bachmann, 1998; Campbell, 2005; Fisher et al., 2000; McGregor et al., 2000; Parti et al., 2016; Wolitzky-Taylor et al., 2011). Supporting the findings above, from a large sample of victims and eight basic reasons for failing to report, Cohn and colleagues (2013) established three main factors of causes: not wanting others to know, the nonacknowledgment of rape, and criminal justice concerns. When exploring the connections between reasons for not reporting and the situational characteristics of the assault, they found that different reasons for not reporting are related to different rape tactics (forcible rape or drug or alcohol-facilitated/incapacitated rape) to varying degrees, depending on how the circumstances relate to the social perception and stereotypical definition of rape (Cohn et al., 2013).

Rape victim advocates (usually NGOs) have proven their potential in resolving issues of trust, improving the victims' experiences with the criminal justice system and in preventing secondary victimization (Ahrens et al., 2007; Brooks \& Burman, 2017; Spohn et al., 2017). Mitigating these problems through the involvement of advocates means removing the barriers created by distrust in authorities and fear of bad treatment, which in turn leads to increased reporting rates (Brooks \& Burman, 2017; Campbell, 2006; Spohn et al., 2017). No advocate support is sustainable however, without increasing awareness of the available support options.

\section{$R M A$}

The factors and reasons influencing victims in their decision to report are neither random nor isolated but in line with the system of beliefs described as "rape myths." Rape myths are "descriptive or prescriptive beliefs about rape (i.e., about its causes, context, consequences, perpetrators, victims and their interaction) that serve to deny, downplay or justify sexual violence that men commit against women" (Bohner, 1998, p. 14, cited in Bohner et al., 2009). These stereotypical beliefs are manifold but can be organized into four general categories: beliefs blaming the victim for their rape, disbelief in claims 
of rape, beliefs exonerating the perpetrator, and beliefs supporting the idea that only certain types of women are raped (Bohner et al., 2009). RMA is a deeply embedded social issue that is related to other tendencies, such as hostile attitudes and behaviors toward women (Lonsway \& Fitzgerald, 1995; Suarez \& Gadalla, 2010), gender role identity, belief in a just world (Lonsway \& Fitzgerald, 1994), and bystander attitudes (McMahon, 2010).

Rape myths are thought to have a dual function: They serve the cultural purposes as defined above but also serve psychological and cognitive purposes (Payne et al., 1999). Research that focuses on the latter has identified general psychological functions such as maintaining cognitive economy, serving as a cognitive schema and building identity, and gender-related functions such as affect management and protecting self-esteem in women and the rationalization of aggressive tendencies in men (Bohner et al., 2009; Snyder \& Miene, 1994).

The fact that rape myths include normative, factual, and evaluative judgments, paired with the cultural and psychological motivations for utilizing them, makes such beliefs especially potent (cf. Reasoned Action Approach; Fishbein \& Ajzen, 2010). This creates a hostile environment for victims that manifests not only in the minds of individuals but also on a societal level by having a very real effect on how society deals with rape. RMs impair objective, nonstereotypical thinking and shape the social perception of rape by serving as easily deployable cognitive schemas. It is important to note that the activation and influential power of rape myths vary between rape cases: Attitudes of victim-blaming are more likely to influence judgment when the observer perceives the rape situation as ambiguous, that is, when the characteristics of the rape case do not match preconceived, stereotypical ideas of rape (see "real rape" below) (Bohner et al., 2009; Frese et al., 2004; Johnson \& Russ, 1989). According to the model proposed by Frese et al. (2004), the perception of rape (responsibility attribution, victim blame, estimation of trauma, and likelihood of reporting) is determined by the interaction between observer characteristics (including RMA) and the situational factors (stranger vs. acquaintance) of the rape case.

\section{Rape Myths and Reporting}

The concept of real rape (Estrich, 1987) is a summary of stereotypical beliefs about rape that set "restrictive criteria for the definition of rape in terms of strangers using force on victims behaving in accordance with normative expectations about female role behavior" (Temkin \& Krahé, 2008, p. 50). The consequences of the real rape concept are harsh: "Since only a small proportion of rapes actually meet these defining features, the real rape stereotype effectively bars many women from being acknowledged as victims of rape" (Temkin \& Krahé, 2008, p. 50). Regarding the issue of underreporting, rape myths contribute to every side of the problem: They affect people around victims, the victims themselves, and those dealing with victims in the social service, health care, and criminal justice system. Indeed, people with high RMA are more likely to blame and disbelieve victims when the perpetrator is an acquaintance or partner, when the perpetrator did not use physical force, when the victim did not resist forcefully, when the victim consumed alcohol or drugs, and when the victim violated traditional gender roles or was deemed "promiscuous" (Frese et al., 2004; Grubb \& Turner, 2012; Hammond et al., 2011; Krahé et al., 2008). People with high RMA are also less likely to recommend that a victim should report to the police (Frese et al., 2004). Results like these offer a clear explanation of why victims might fear the judgment of others and often refrain from reporting.

Rape myths do not only hinder reporting by creating a social environment in which it is discouraged but also make it difficult for victims to assess their situation. Victims with high RMA are considerably less likely to report to the police, especially if the characteristics of the sexual assault do not match the stereotypical real rape scenario; conversely, if the incident does match the real rape myth, reporting is more likely (Allen, 2007; du Mont et al., 2003; Frese et al., 2004; Heath et al., 2013; Wilson \& Scholes, 2009; Wolitzky-Taylor et al., 2011). This correlation between RMA, situational characteristics, and reporting to the police is explained by the term "unacknowledged rape." Simply put, victims who do not label their sexual assault as "rape" are less likely to report to the police (Cohn et al., 2013; Paul et al., 2014; Spohn et al., 2017). Not acknowledging the incident as rape, nor seeing themselves as victims who deserve assistance or the incident as a crime worthy of reporting has, logically, a strong impact on the decision to report. In this regard, the role of rape myths influences the perception of victims by generating uncertainty in defining nonstereotypical incidents as rape (Chen \& Ullman, 2010; Cohn et al., 2013; Heath et al., 2013; Littleton et al., 2006) and by discouraging them from reporting incidents out of fear that authorities will not believe them (Sabina \& Ho, 2014). Studies exploring the connection between rape myths and rape acknowledgment found that victims with high RMA are less likely to label nonconsensual sex as rape (Peterson \& Muehlenhard, 2004; Spohn et al., 2017).

\section{Rape Myths and the Criminal Justice System}

After illustrating how rape myths influence the general population and the victims themselves in the perception and reporting of rape, the following section will focus on the impact authorities have on rape reporting rates and discuss how rape myths affect those working with rape victims in the criminal justice system.

Research suggests that about two thirds of victims tell somebody about their rape (Ahrens et al., 2007; Fisher et al., 2003), but instead of the authorities or support organizations, they typically disclose the information to informal sources like family and friends (Ahrens et al., 2007). As previously mentioned, one of the main reasons victims give for not reporting rape is a fear of the criminal justice system, more precisely, the fear of police not believing them, being biased against them, and the report then having no effect (Allen, 2007; Bachmann, 1998; 
Fisher et al., 2000; McGregor et al., 2000; Parti et al., 2016; Wolitzky-Taylor et al., 2011). This means that victims have no trust in authorities when it comes to providing justice and support in rape cases, and research suggests that these fears are oftentimes justified.

People working in the criminal justice system seem to be just as affected by rape myths as anyone else-statistics reflect the same tendencies, such as that male officers have higher RMA and are more likely to blame victims (for a review, see Parratt \& Pina, 2017) — but this carries harsher consequences for victims. Rape myths do not singularly determine how police officers deal with rape cases. Other attitudes and legal and procedural considerations like the perceived likelihood of the perpetrator being convicted may also influence the decisions of police officers (Frazier \& Haney, 1996; Schuller \& Stewart, 2000; Stewart \& Maddren, 1997). However, rape myths do have a strong impact on how police officers perceive and judge rape cases and victims - especially victim credibility and responsibility attribution-which can greatly influence their decision making during procedures and their behavior with victims (Jordan, 2004; Temkin \& Krahé, 2008). Due to the same previously discussed factors, suspicion against rape reports among police officers (Jordan, 2004) shows that rape myths can tip the balance of perceived credibility and responsibility in the perpetrator's favor. Factors such as victim-perpetrator relationship (Frazier \& Haney, 1996; Sleath \& Bull, 2012; Venema, 2014), the involvement of substance use or behavior deemed "immoral" or "promiscuous" (Jordan, 2004; Schuller \& Stewart, 2000), the presence or lack of serious physical injury (Frazier \& Haney, 1996; Schuller \& Stewart, 2000), and the concealment of certain circumstances (usually out of fear of being judged) during the investigation (Jordan, 2004) all influence the likelihood of police officers blaming and disbelieving the victim. The real rape and "real victim" stereotypes seem to have a relevant impact on police officers as well, which actively influences the judgment and perception of rape victims (Krahé, 1991; Page, 2008).

Although research is scarce on RMA among judges (Bendixen et al., 2014) and prosecutors (Gylys \& McNamara, 1996), there are studies on how rape myths appear in court procedures. Analysis of court proceedings show that rape myths are routinely used at trial by defense lawyers and are often not challenged, countered, or resisted by judges or prosecutors (Lovett et al., 2007; O. Smith \& Skinner, 2017; Temkin et al., 2018). Temkin et al. (2018) identified three distinct ways in which rape myths are used as an attempt to discredit the victim, to conceptually distance the case from the stereotypical real rape scenario, and to underline aspects of the case that match rape myths. The use of rape myths in court revolves around creating doubt and suspicion toward the credibility of the plaintiff, for example, by creating an extreme dichotomy of completely trustworthy/untrustworthy witnesses or denying that fear is a valid justification for the victim's actions (Burrowes, 2013; O. Smith \& Skinner, 2017). Other rape myth narratives are used to deliberately oversimplify the rape incident or to create a false norm and expectation of "rational" behavior for victims, labeling behavior not fitting into this norm as "inconsistent" and thus suspicious or blameworthy (Lovett et al., 2007; O. Smith \& Skinner, 2017). Eyssel and Bohner (2011) suggest that the "subjective feeling of entitlement to judge" enhances the biasing effects of rape myths, thus making them even more relevant under the circumstances of a trial.

Fears of victims are also justified by negative experiences with the criminal justice system. The well-known term of "secondary victimization" describes the further traumatization of victims as the result of investigative and trial processes (Madigan \& Gamble, 1991). Research involving victims, members of the criminal justice system, members of the healthcare system, and rape victim advocates all suggest that rape victims typically have a negative experience of interacting with police, legal, or support personnel, due to the insinuation of blame and disbelief in their line of questioning or behavior (Campbell, 2006; Campbell et al., 2001; Maier, 2008). Interviews with personnel also show that those dealing with rape victims underestimate their potentially negative impact and are unaware of the effect they are having on victims (Campbell, 2005). Next, we turn to the Hungarian case in order to discuss the presence of the abovementioned factors and how they may hinder rape reporting.

\section{The Hungarian Case}

According to Hungary's Criminal Code (Sections 196-198, Act 100 of 2012), sexual violence can be committed without physical force, within a marriage, against victims of any age (sexual abuse against minors), and is not limited to penetration via sexual organ or object; the law protects sexual selfdetermination. Although the definition of sexual violence seems clear and straightforward, the way society judges the act, the actor, and the victim can be harshly different.

Well-publicized cases of sexual violence in Hungary involve institutions including colleges, athletic teams, and theaters. In 2016, prominent Olympic medalist and coach László Kiss was convicted for a gang rape which occurred 55 years prior. After his incarceration, he resumed coaching and received awards. In the autumn of 2017, during the Hungarian \#MeToo wave, an actress accused a famous theater director of sexually assaulting her 20 years prior. The denial of gender equality, the disregard of bodily integrity, the normalization of violence in performance sports, the acceptance of sexual harassment in the arts, and the highly sexualized atmosphere of university freshman camps - where rape occurs-have also been brought to light in Hungarian society (Petö, 2019). In each and every case, public opinion was divided and disparaging voices blamed victims and sought excuses for perpetrators. In the László Kiss case for instance, as a successful person who was popular and powerful, people tended to exonerate him (Nyúl et al., 2018) because he had already served a prison sentence. Contrastingly, feminist and victim advocate groups demanded his resignation. Kiss finally resigned, despite the Hungarian Association of Swimmers officially standing up for him (Petö, 2019), and only after several months of social and 
political discourse in which his merits as a national coach were weighed against the heinous crime he had committed in the past. The case also shed light on the underlying nature of structural power abuse that suffuses institutions such as competitive sport and higher education.

As another impact of the \#MeToo movement, Hungarian actress Lilla Sárosdi posted a video on her Facebook page that detailed an episode of her early career when she, as an aspiring drama student, was sexually molested by a successful theater director (Papp, 2018). Having happened decades earlier, the public also questioned Sárosdi's morals and the story was downplayed, but after the alleged perpetrator threatened to sue, an additional six women testified anonymously against the theater director and two more allegations were filed within a week citing stories similar to Sárosdi's. A public debate emerged that emphasized the professional merits of the perpetrator. Public media figures voiced their concerns and disbeliefs (Papp, 2018). After several months, the director retired from his positions held at public institutions.

Although it is necessary to generate public debate over someone's accountability for misusing power, this can easily create an atmosphere in which pertinent agencies such as the criminal justice system and even victims themselves may become uncertain in evaluating the appropriate call for justice. The general anxiety raised by discourse in the public sphere about sexual violence is akin to annihilation anxiety (Robinson $\&$ Gadd, 2015). Such public attention to sexual victimization raises fears both conscious and unconscious. On the microlevel, divided public opinions can compromise one's willingness to confront perpetrators; on the meso and macrolevels, disparate voices can promulgate stigmatization, a reluctance to support victims, and official resistance against engaging in further policy development or analysis concerning prevention and intervention.

These events underscored the need to increase sensitization among law enforcement officials, to respect and highlight the rights of victims, and to support those victims. Parti et al. (2016) conclude that the recent example of publicly exposing RMA in Hungary have led to (1) a general public discourse about sexual violence and its underreported prevalence and (2) a greater amount of public campaigns by victim protection agencies aiming to redirect responsibility from victim to perpetrator (e.g., the civil organization A Nem Az Nem, "No Means No" was founded in 2015 as a response to the statewide debate on the legitimacy of the concerns of sexual crime victims; Parti et al., 2016). However, research indicates that stereotypes supporting sexual victim blaming is still very prevalent in Hungary, even among the most educated citizens (Parti et al., 2016).

\section{RMA in Hungary}

As a recent survey shows, rape myths are widely held in Hungary, and RMA is prevalent even among those who identify as being sensitive to and concerned with the subject (Parti et al., 2016). In an international study representing and comparing gender-based values in EU member states, Hungarian participants were on average twice as likely to believe that "having sexual intercourse without consent may be justified in certain situations." Rates were also double the EU average for those "situations including drug and alcohol use," "voluntarily going home with someone," "and wearing revealing, provocative or sexy clothing" (Eurobarometer, 2016, 2017). Although with less divisive opinion, Hungarian respondents still agreed more with victim blaming statements than the average European: $44 \%$ of Hungarians thought that women are more likely to be raped by a stranger than an acquaintance, $23 \%$ thought that women often exaggerate or lie about abuse or rape, and $22 \%$ thought that women often provoke violence (Eurobarometer, 2016; see Table 1). According to Eurobarometer's findings, Western European countries are more progressive in terms of gender equality values than countries in Eastern Europe. In the European context, Hungary falls far behind in indicators of gender equality in terms of policy, law, and culture (Eurobarometer, 2016, 2017). This is reflected by the way in which Hungarians think about the societal and familial roles of females and males; for instance, in perceiving crying as being a sign of weakness in men and in holding overall stereotypical beliefs toward gender roles and the right of women to pursue professional ambitions outside the family. Table 1 conveys in stark terms the broad range of attitudes toward gender roles across countries, as measured by the Eurobarometer.

RMA has not been studied in Hungary with a nationally representative sample, but a large $(n=6,679)$ sample of social media users reflect a relatively high RMA level (Parti et al., 2016). Parti et al. collected data on a voluntary survey advertised on Facebook in 2016, the largest social media network in Hungary at that time. The research reflects the attitude toward sexual violence of a relatively small minority of the population, and respondents can be considered as showing interest in the topic of sexual violence; $35.5 \%$ of survey participants believed that offenders suffer from mental illness, another $37 \%$ believed that he acts out of an uncontrollable passion, $35.5 \%$ believed that sexual violence partners with physical violence, and $27 \%$ agreed with the idea that offenders usually act under the influence of drugs or alcohol (Parti et al., 2016). Victim blaming was significantly correlated to cognizance: Those with less knowledge about current sexual violence laws and rape myths were more likely to believe that victims precipitate the crime or even provoke perpetrators (Parti et al., 2016). In contrasting, those who had themselves been sexually victimized were significantly less likely to believe that victims precipitate or provoke the crime through alcohol consumption, being attractive, wearing certain clothing, or behaving in a certain way (Parti et al., 2016).

The high rate of RMA and sexist attitudes as presented in the study above - as well as in comparison to representative samples from other European nations - suggests that Hungarian society is still rather patriarchal and more likely to convey machismo values than other countries in the region. Rape myths are prevalent in the general society, as well as in the criminal justice system. 
Table I. Gender Equality and Gender-Based Violence Survey Data.

Gender Equality (in 26 Member States; Eurobarometer, 2017)

$87 \%$ of participants in Hungary said women are more likely than men to make decisions based on their emotions (the largest rate within the surveyed countries, compared to $47 \%$ in Sweden, $53 \%$ in Spain, and $57 \%$ in France; European Union [EU] average: 69\%)

$78 \%$ of participants in Hungary answered that the most important role of a woman is to take care of her home and family (Bulgaria: $81 \%$, Sweden: II\%, and EU average: $44 \%$ )

$79 \%$ of participants in Hungary said the most important role of a man is to earn money (Bulgaria: $81 \%$, Sweden: $10 \%$, and EU average: $43 \%$ )

Only $77 \%$ of participants in Hungary said it is okay for a man to cry (Eastern European average: $62 \%-82 \%$, EU average: $88 \%$, and Western EU: 91\%-99\%)

Respondents in Hungary (II.3) are the second most likely after Bulgaria (12.4) to stereotype based on gender (the lowest is Sweden: 3.0, Denmark: 4.4, and the Netherlands: 4.6; EU average: 7.3 )

$89 \%$ of Hungarian respondents think promoting gender equality is important to ensure fair and democratic society (this is in concert with most of Europe; EU average: $91 \%$, Greece: $80 \%$, and Portugal: 98\%)

$74 \%$ of Hungarians approve a man doing an equal share of household activities and taking parental leave (EU average: $84 \%$, Lithuania: $64 \%$, and Denmark: 95\%)

Hungarians are the least likely (56\%) to believe men are more ambitious than women (EU average: 35\%, Sweden: 96\%, Czech Republic: 58\%, and Romania and Slovakia: 62\%)
Gender-Based Violence (in 16 Member States; Eurobarometer, 2016)

Participants in Romania (30\%) and Hungary (24\%) are the most likely to say being drunk or using drugs justifies sexual intercourse w/o consent (Sweden/Finland/Denmark: 2\%; EU average: I2\%)

At least one in five respondents $(20 \%)$ in Hungary thinks intercourse without consent is justified if a person voluntarily goes home with someone (Sweden: 3\% and EU average: II\%)

After Romania, Hungary is the second $(21 \%)$ most likely to say that sexual intercourse without consent is justified if the person is wearing revealing, provocative, or sexy clothing (Sweden: $2 \%$ and EU average: $10 \%$ )

Respondents in Hungary are the most likely (19\%) to say intercourse without consent is justified if the person was flirting beforehand or was out walking alone at night (18\%; EU average: $7 \%$ )

Participants in Romania (20\%) and Hungary (18\%) are the most likely to say having several sexual partners is justification for intercourse without consent (EU average: 7\%)

$44 \%$ of Hungarian participants think that women are more likely to be raped by a stranger than an acquaintance (EU average: $31 \%$ )

$23 \%$ of Hungarian participants think that women often exaggerate or lie about abuse or rape (EU average: $22 \%$ )

$22 \%$ of Hungarian participants think that women often provoke violence (EU average: $17 \%$ )

Source. The authors, adapted from Eurobarometer (2016) and Eurobarometer (2017).

\section{Experiences of Victims Within the Criminal Justice System}

A recent analysis of 155 case files of sexual violence by Parti et al. (2017a) shows that the prevalence of rape myths in the Hungarian criminal justice system is similar to the global average. The researchers analyzed the case files according to what questions the victim is asked during the interview by police in the investigation phase and by the judge at the trial phase, as well as by any references included in the case files which discuss the victim's possible precipitation. Insinuative references/questioning toward the victim's provocation appeared in $18 \%$ of cases, references/questioning about the victim's clothing or substance use at the time of the offense appeared in $16 \%$ of the cases, and references to the "mental state" of the victim appeared in $62 \%$ of the cases. Consistency of the victim's account, the time passed between victimization and filing a report appeared among cases as a measurement of victim credibility. Despite the introduction of marital rape into the Hungarian criminal law in 1997, a marital relationship between perpetrator and victim is used as an extenuating circumstance in criminal procedures (Parti et al., 2017a).

Another potential explanation for low reporting rates is a lack of trust in other people and in institutions, especially concerning the police. Eastern European countries tend to demonstrate a traditionally lower level of trust in the police, as well as in other governmental agencies including the judiciary, as compared to Western European and Scandinavian nations (ESS Statistics Netherlands, 2019). In 2012, Eastern European countries showed an average trust level of 4.5 in the police, which is 2.4 points lower than that of Western European countries (avg. 6.7; ESS Statistics Netherlands, 2019). Further disparities can be observed between victims and nonvictims, with victims having a lower trust in the police as compared to nonvictims (Staubli, 2017). It is important to note that negative experiences with the police by victims lead to a reduction in their trust, while, conversely, the police can gain trustworthiness in the eyes of victims by treating them correctly (Staubli, 2017). Although slowly increasing, trust in institutions and the police is still generally low in Hungary (Boda \& Medve-Bálint, 2014; Bodor \& Grünhut, 2015) and trust in others is among the lowest in the EU (Bodor \& Grünhut, 2015; Eurostat, 2015). Trust is a prerequisite of disclosure which in turn has an impact on reporting rates. Encouragement and support from others significantly increase the likelihood of reporting and a continued participation in the criminal justice system (Allen, 2007; Filipas \& Ullman, 2001; Patterson \& Campbell, 2010; Paul et al., 2014).

To put the numbers reported above into context, let us discuss the history of feminism and the role politics played in 
forming Hungary's unique atmosphere which is still a hindrance to the reporting of sexual violence today. Feminism has never fully fledged in Hungary, but due to the process of dedemocratization as started in 2010 (Bogaards, 2018), the politicization of gender ideology (also known as "gender mainstreaming") directly affects the well-being of sex crime victims.

\section{A Historical Approach to Feminism in Hungary}

Feminism in Hungary can be traced back to the second part of the 19th century. Similar to other countries, the main topics of first wave feminism were around education and voting rights, wherein some considerable steps were in fact achieved. Hungarian women received voting rights in 1918 (Szécsi \& Géra, 2015) and voting rights equal to those of men in 1945. Despite these early achievements, WWII and the subsequent communist takeover and Soviet occupation destroyed the momentum of grassroots feminism.

The mass rape committed by Soviet soldiers in Hungary at the end of WWII was a collective trauma followed by a "conspiracy of silence" (Peto", 2003, p. 131). In the new dictatorship secured by the Soviet Union, publicly (or even privately) speaking about anything which would reflect badly on the "liberating" Red Army was unimaginable. But even apart from the political circumstances, discussing rape was taboo and the nondisclosure of information regarding the mass rape only deepened its taboo status (Petö, 2003). The collective processing of traumatic experiences for women and girls had not even started until Petö's (2018) recent publication on war crimes against Hungarian women. Even in Western European countries, thematization and academic research on rape started relatively late, with the second wave of feminism not coming until the 1970s, but these changes stopped at the Iron Curtain without reaching Hungary.

Another backlash to feminism happened in 1949, when the political dictatorship abolished civil organizations, including the Feminist Association which had played a key role in activism and advances toward feminist emancipation. The rather underdeveloped civil sphere simply stopped existing. No opinion different from the official political one was allowed in the public space, and this was true for the "women question" as well. According to the propaganda, equality, including gender equality, had been achieved. In reality, this equality existed only in writing, in the language of the Constitution, which proclaimed the principle of gender equality (1949), and the (forced) full employment of women. Parallel to this and concurrent with traditional gender role expectations, inequalities in work and in private life persisted, which created the double burden of work and household tasks for Hungarian women (Acsády, 2018). Marital rape was not recognized until 1997, when a legislative amendment introduced this legal category to the Hungarian Criminal Code. The new constitution (The Fundamental Law of Hungary, April 25, 2011) is regressive from a feminist perspective, as it confines marriage to binary couples: "marriage [as] the union of a man and a woman established by voluntary decision [...]," (Article L) and emphasizes the requirement of children for a unit to qualify as a family: "Family ties shall be based on marriage or the relationship between parents and children." (Article L).

The so-called Democratic Opposition began to coalesce in the 1970s and became an important player during the political transition in 1989/1990. Although it had many female members, the Democratic Opposition did not thematize the controversial situation of women but instead accepted the official opinion and considered the "woman question" a resolved one. The reality was that sexist attitudes were just as widespread within this group as anywhere else in wider society (Acsády, 2018).

Since 2010, when Viktor Orbán was elected as prime minister for a second time after the political transition, a second wave of civil discourse emerged, this time around "gender." The concept of gender was and still is positioned as a major threat by right-wing-controlled media, but also, and even more importantly, in the Parliament, where it became part of the conservative political discourse with a clear ideological motive (Barát, 2018).

Women have historically been framed as reproducers of the nation (McClintock, 1993), whose duty to their country is to biologically secure the nation's progeny. The resurgence of right-wing and ethno-nationalist movements across the globe (Bieber, 2018) should serve as a warning against the Hungarian government's policy that aims to control gender and sexuality. In 2019, the government launched the "Family Protection Action Plan" (FPAP) with the goal of boosting demographic growth in the country (Kovács, 2019). The plan, which declared 2019 as "the year of the family," incentivizes ethnic Hungarian women to fulfill their duty to bear multiple children. The most generous financial benefits are allocated to those women who give birth to four or more children (Inotai, 2019). With the initiation of FPAP, Hungary's right-wing government aims to tackle the demographic decline through asserting the primacy of heteronormative nuclear families and traditional gender roles. The Hungarian government's rightwing nationalist program is well-fitted into the anti-gender movements emerging in several member states of the EU (for an overview, see Vida, 2020). The anti-gender movements among EU member states are governed around a common goal: to mobilize against the "gender ideology" that is allegedly undermining the demographic survival of member states through the narrative of gender equality. Gender ideology or the politicization of gender is seen as

a rhetorical tool to mobilize hate, framing progressive ideas about gender values, human rights and equality as a threat to those actors and institutions whose traditional position and identity became challenged by the transformative goals of feminist politics and the gender equality project. (Grzebalska et al., 2017)

As part of the suppression of gender ideology, the government banned gender studies programs at Hungarian universities in 2018 (Timár, 2019) and has implemented restrictions on 
LGBTQ+ (Lesbian, Gay, Bisexual, Transgender, Questioning; plus represents diversity) rights (Vida, 2020) including the introduction of a new amendment in the Fundamental Law which limits adoption to married couples in 2020 and thus prohibits adoption for nonheterosexual couples who cannot legally marry in the country (Human Rights Watch, 2020).

For similar reasons, the Istanbul Convention on Combating and Preventing Violence Against Women does not fit into the conservative political agenda and thus remains to date unratified. The Istanbul Convention was signed by Hungary in 2014 and is the first legally binding instrument dedicated to combating violence against women. It was a milestone in women's rights protection, since it requires ratifying states to allocate an annual budget to the support of victim services such as legal and psychological consultation, helplines, shelters, and other forms of support. The Hungarian government refused to ratify it, arguing that, by singling out women who need protection from their family members, as well as by explicitly mentioning immigrant women as those in need of governmental protection from exploiters, the Convention promotes "destructive gender ideologies" and "illegal migration" (Didili, 2020). The narrative of victim support services being illegal by providing aid to victims of (nonexistent) family violence and illegal migration is not new to Hungarian politics. In 2017, the Hungarian Parliament passed legislation imposing severe restrictions on NGOs that receive foreign funding. Although the government argued that the policy was necessary to protect national security and to ensure transparency, critics says its real purpose was to stigmatize, discredit, and intimidate civil organizations who are crucial in helping victims of human trafficking and domestic violence (Serhan, 2017).

\section{Macro- and Microlevel Gender Politics in Hungary}

Macro and microlevel gender politics can best be described through the example of the elimination of gender studies programs in Hungary (Timár, 2019). The current political rhetoric advocates its leading ideas through three "great issues": Christian culture versus multiculturalism, anti-immigration versus pro-immigration policies, and the Christian family model versus "adaptable family models" (Serughetti, 2019). Studies that are by their very nature critical toward power, or questioning of gender, sexual, social, and racial hierarchies and their intersectionality, represent a threat to the authoritarian aspirations of the ruling elite (Serughetti, 2019). Therefore, the ban on gender studies programs represented not only a threat to academic freedom but was also part of a larger political campaign aimed at discrediting those institutional bodies critical of the political regime. Placing the nuclear, heterosexual family onto the pedestal in order to boost reproduction is a key ideological message. On the other hand, gender discourse could play an important role in democratic development by advocating reproductive rights and gender diversity as cornerstones of democratic rights. The banning of gender studies represented a symbolic display of force as it was seen as a significant challenge against "illiberal democracy." In line of the process of authoritarianization (Buzogány, 2017), the political agenda of "illiberal democracy" was proclaimed by Hungarian prime minister Viktor Orbán as a model for other conservative political parties to follow within the EU (Krekó \& Enyedi, 2018). Gender ideology was framed by the political regime as a "failure of liberal democracy," and gender studies have been identified and misinterpreted as "feminism as a movement towards reinventing matriarchy and boosting gender issues such as transgenderism and a force able to change people's gender" (Serughetti, 2019: 3). Consequently, gender studies, which represent liberal values and the fluidity of traditional gender roles, must be banned from higher education.

\section{Familialism's Discriminatory Nature Against Women With Social Reproductive Care Duties}

The cornerstone of the Hungarian illiberalism project is "familialism" (Yang, 2006, p. 15), a policy-oriented form of "familism." The latter is an ideology placing family as the central focus of a political campaign, as reflected in the abovementioned FPAP. Familialism on the other hand, is "a form of biopolitics which views the traditional family as a foundation of the nation" and "subjugates individual reproductive and selfdetermination rights to the normative demand of the reproduction of the nation" (Grzebalska \& Petö, 2018, p. 167).

During the political transition in $1989 / 1990$, emancipation via the labor market was available only to women in privileged positions. This refers to women who, despite state health and reproductive care institutions being underfinanced, were wealthy enough to outsource family care to informal and unregulated circles, such as immigrant caretakers or their own family members, and were thus able to go out and find employment. This notion is referred to as "distorted emancipation" (Hochschild, 2000; Uhde, 2016; cited by Gregor \& Kováts, 2019), a product of the political and economic transition which is still maintained in current populist political regimes.

In the shadow of population decline, the Hungarian government is pursuing a selective pro-natalist policy by providing cash transfers to couples with employment status under the condition that they reproduce multiple children in the future. However, this incentive is not offered equally to every couple, but only to those with higher socioeconomic status which, paired with the dismantling of family care institutions such as nurseries, puts an enormous burden on family members whose traditional job is to provide social reproductive care at home, that is, child and elderly services. The term "gender regime" refers to an interconnected system of individual and public terrains such as economy, policy, and gender roles in the family in which interpersonal and institutional practices shape gender relations (Walby, 2011, p. 7; cited by Gregor \& Kováts, 2019). Gregor \& Kováts (2019) claim in their study that managing work and childcare duties is the largest problem of employees who have children as the neoliberal gender regime only provides family support (cash transfers) for the better-off classes. 
While the conservative ideology of the governing parties can very well incorporate women's paid labor on the pragmatic level, the fact that market actors have such a huge influence on the state (at least the legitimacy of the political system is dependent on economic success, at worst, transnational companies might directly influence labor policies), it makes it impossible to address the burden on families, and-given the unequal share of unpaid work - on women. (Gregor \& Kováts, 2019, p. 111)

The current populist ideology, which attacks gender studies and the individual rights of women, aims at serving underlying economic goals. Eliminating gender ideology and banning gender studies are only some of the tools applied by the political regime in order to lure more people into the market of paid work and boost the country's economy (Gregor \& Kováts, 2019). Recent studies show, however, that this will be in vain until the government strengthens health care and social reproductive care institutions in order to lighten the burden of families (Gregor \& Kováts, 2018, 2019). Furthermore, flexible work hours and equal wages would be necessary to provide support for women, who are not only responsible for reproduction but also for the traditional home care providers.

What do gender ideology and, as part of it, "familialism" have to do with the reporting of sexual violence? Since most victims of sexual violence are female, and most sexual violence is committed by acquaintances or family members, a political agenda that emphasizes and rewards traditional gender roles and societal power structures thereby suppresses the equal rights of women, their right to reproductive freedom, and their right to live an economically independent life. By incentivizing the bearing of multiple children, unprivileged women living under economic pressure are coerced into producing multiple children and burying themselves in the unpaid work of social reproductive care duties, traditionally allocated to women. This ideology is particularly harmful to women who are victimized within their families but cannot leave since there is no Plan B for them in the economic market. They cannot ask for help because their neighbors respect familialism, and they consider sexual violence to be justifiable outside of real rape scenarios, that is, within the family. They cannot even turn to NGOs, since civil organizations helping victims are either underfinanced or nonexistent (i.e., financially unsupported or banned by the government). In a country where there is no international convention (i.e., the Istanbul Convention) requiring the government to provide an annual budget allocation to victim support services, a woman who flees from home cannot hope to find accommodation in a shelter or secure protection from a batterer.

\section{Discussion}

Historically, rape is an underreported crime worldwide, but Hungary stands out with an exceptionally low reporting rate. By measures of gender equality, the Western part of Europe presents a markedly more progressive policy agenda and practice compared to the former Soviet Bloc where women serve traditional gender roles inferior to men in society that are imposed throughout their lives. Forms of nonconsensual sexual intercourse and gender-based violence have been exculpated in policy and everyday life, despite current feminist movements that have appeared in social media and have, undoubtedly, triggered social debate. RMA, a principal dimension of rape culture, clearly influences reporting affinities in public discourse and behavior, among police, and throughout the criminal justice system. General trust in institutions is low, including trust in police attitudes, integrity, and the duty to enforce laws about gender-based violence; such mistrust further hinders reporting. Current studies show that Hungary is not exempt from this. Once a crime is reported, the victim is exposed to secondary victimization, on a variety of levels, for example, by biased interview techniques, including details in the case files resembling (but not refuting) real rape scenarios (e.g., what the victim wore when the crime was committed) and applying these as mitigating circumstances in sentencing the offender.

Gender politics fail to provide a nurturing environment for victims to feel supported. In the current political discourse in Hungary, the population and demographic crisis is the most unnerving issue, which should be solved by supporting families and strengthening traditional gender values. In this framework, women are mainly seen as mothers, as inextricable members of their families, instead of as independent individuals with human rights (Pivarnyik, 2018). The political regime depicts gender ideology as a failure of liberal democracy; hence, gender-thematized rights and institutions are scapegoated and eliminated. Policy-oriented familism has been introduced in order to overcome the country's population shortages and economic hardships. This increases the social and labor burden of women, designating them - in policy and practice - as the ones responsible for social reproductive care. Emancipation was originally distorted by not providing equal market opportunities for underprivileged and marginalized women. Furthermore, current pro-natalist policies bring little ease to women's lives, as they are facilitated by neither adequate health care nor by social reproductive care institutions, and wages remain unequal across genders.

In Hungary, gender inequalities are maintained by the strength and appeal of political forces, driven by populist ideologies that serve demography-based economic demands, to ensure that the country will survive and even thrive. Therefore, the marked shortage of services such as victims' care and education geared toward dismantling rape myth ideologies is not at all surprising in Hungary. In addition to RMA within society and the criminal justice system, the low level of trust in authorities, a reason for underreporting in general, reflects the larger picture of a neoliberal gender regime.

This review provides context for the underreporting of rape, with specific focus on how attitudes, laws, and traditions influence RMA in Hungary. Hungary is in contrast with more progressive nations in the larger context of the Western world, a context that we have employed as a foundation for our work on victims of sexual violence - how they are served in Hungary, how their needs are recognized, and how they are perceived by professionals. There is a need for further research into the 
perspectives of practitioners, NGOs, and every level of Hungary's criminal justice system.

\section{Research and Policy Implications}

The Hungarian case has important implications for understanding the nature of underreporting sexual violence globally. Although research is limited and statistics nearly nonexistent, the existing research on sexual violence victimization in Hungary shows an alarming rate of underreporting, even compared to neighboring countries. The Hungarian case shows possible underlying causes and factors that hinder reporting. Further research is needed to study how political agendas such as family-supporting or birth-rate-enhancing policies affect the individual's understanding of domestic and sexual violence and how these policies affect a victim's perception of support and blame when reporting their victimization. Research has to address the availability and the quality of government-based victim support services. On the policy level, civil organizations helping victims of sexual violence and exploitation must be recognized and strengthened by providing state support.

Governments, in pursuing a more prosperous economy, must realize that such a goal cannot be achieved without helping women in their familial duties. Providing paid reproductive care services enhances productivity by allowing for more women to enter into the paid workforce. Building a career outside the family can help victimized women gain economic strength, thereby lessening their dependence on abusive partners and improving their chances of economic survival after divorce. Instead of forcing women to remain in unhealthy relationships, women must be afforded access to services that help them overcome the economic and psychological burden of such relationships and foster their ability to raise children in nonabusive households. The first step in this process might be to provide sex education which teaches about the early recognition of abusive relationships to youngsters in educational institutions. Female freedom is key in achieving economic prosperity. Our findings suggest that increasing the population and promoting a livable country are not achievable without recognizing women's rights.

\section{Declaration of Conflicting Interests}

The author(s) declared no potential conflicts of interest with respect to the research, authorship, and/or publication of this article.

\section{Funding}

The author(s) disclosed receipt of the following financial support for the research, authorship, and/or publication of this article: The research project has been supported by Fulbright Commission of Hungary and the National Institute of Criminology Hungary in 2017 and 2018.

\section{ORCID iD}

Katalin Parti (D) https://orcid.org/0000-0002-8484-3237

\section{Supplemental Material}

The supplemental material for this article is available online.

\section{References}

Acsády, J. (2018). Államszocializmus_nők—ellenzékiség [State socialism-women-opposition]. Társadalmi Nemek Tudománya Interdiszciplináris Folyóirat, 8(1). http://tntefjournal.hu/vol8/iss1/ acsady.pdf

Ahrens, C. A., Campbell, R., Ternier-Thames, N. K., Wasco, S. M., \& Sefl, T. (2007). Deciding whom to tell: Expectations and outcomes of rape survivors' first disclosures. Psychology of Women Quarterly, 31, 38-49.

Allen, W. D. (2007). The reporting and underreporting of rape. Southern Economic Journal, 73, 623-641.

Bachman, R. (1998). The factors related to rape reporting behavior and arrest. New evidence from the National Crime Victimization Survey. Criminal Justice and Behavior, 25, 8-29.

Barát, E. (2018). Az előjogainak sérülését helyreállítani igyekvő "dühös államférfi" "nő"-ellenes hadjárata ["Mysognist" war of the "furious statesman" in an urge to restore harmed prerogatives]. Társadalmi Nemek Tudománya Interdiszciplináris Folyóirat, $8(1), 32-45$.

Bendixen, M., Helle, S., Langbach, T., \& Rasmussen, K. (2014). Voldtektsmyter og kjønnssjåvinisme blant norske lekdommere og fagdommere [Rape myths and sexism among Norwegian judges]. Tidsskrift for Norsk Psykologforening, 51, 7-13.

Bieber, F. (2018). Is nationalism on the rise? Assessing global trends. Ethnopolitics, 17(5), 519-540.

Boda, Z., \& Medve-Bálint, G. (2014). Does institutional trust in East Central Europe differ from Western Europe? European Quarterly of Political Attitudes and Mentalities, 3(2), 1-17.

Bodor, Á., \& Grünhut, Z. (2015). Társadalmi rétegződés Magyarországon a bizalom mentén [Social stratification in Hungary along the level of trust]. Századvég, 78(20), 19-47.

Bogaards, M. (2018). De-democratization in Hungary: Diffusely defective democracy. Democratization, 25(8), 1481-1499.

Bohner, G. (1998). Vergewaltigungsmythen [Rape myths]. Verlag Empirische Pädagogik.

Bohner, G., Eyssel, F., Pina, A., Siebler, F., \& Viki, G. (2009). Rape myth acceptance: Cognitive, affective and behavioural effects of beliefs that blame the victim and exonerate the perpetrator. In M. Horvath \& J. Brown (Eds.), Rape: Challenging contemporary thinking (pp. 17-45). Willan.

Brooks, O., \& Burman, M. (2017). Reporting rape: Victim perspectives on advocacy support in the criminal justice process. Criminology \& Criminal Justice, 17, 209-225.

Brownmiller, S. (1975). Against our will: Men, women and rape. Simon and Schuster.

Burgess, A. W., \& Holmstrom, L. L. (1974). Rape trauma syndrome. American Journal of Psychiatry, 131(9), 981-986.

Burrowes, N. (2013). Responding to the challenge of rape myths in court: A guide for prosecutors. NB Research.

Buzogány, A. (2017). Illiberal democracy in Hungary: Authoritarian diffusion or domestic causation? Democratization, 24(7), 1307-1325. 
Campbell, R. (2005). What really happened? A validation study of rape survivors' help-seeking experiences with the legal and medical systems. Violence and Victims, 20(1), 55-68.

Campbell, R. (2006). Rape survivors' experiences with the legal and medical systems do rape victim advocates make a difference? Violence Against Women, 12, 30-45.

Campbell, R., Wasco, S., Ahrens, C., Sefl, T., \& Barnes, H. (2001). Preventing the "second rape": Rape survivors' experiences with community service providers. Journal of Interpersonal Violence, 16, 1239-1259.

Chen, Y., \& Ullman, S. E. (2010). Women's reporting of sexual and physical assaults to police in the national violence against women survey. Violence Against Women, 16, 262-279.

Cohn, A. M., Zinzow, H. M., Resnick, H. S., \& Kilpatrick, D. G. (2013). Correlates of reasons for not reporting rape to police: Results from a national telephone household probability sample of women with forcible or drug or- alcohol facilitated/ incapacitated rape. Journal of Interpersonal Violence, 28(3), 455-473.

Didili, Z. (2020). Hungary refuses to ratify Istanbul Convention on violence against women. New Europe, May 7, 2020. https:// www.neweurope.eu/article/hungary-refuses-to-ratify-istanbul-con vention-on-violence-against-women/

du Mont, J., Miller, K., \& Myhr, T. L. (2003). The role of "real rape" and "real victim" stereotypes in the police reporting practices of sexually assaulted women. Violence Against Women, 9(4), 466-486.

ESS Statistics Netherlands. (2019). Trust in others, legal system and politics; European comparison. CBS Open Data Statline. https:// opendata.cbs.nl/statline/\#/CBS/en/dataset/80518ENG/table? $\mathrm{dl}=165 \mathrm{CC}$

Estrich, S. (1987). Real rape: How the legal system victimizes women who say no. Harvard University Press.

Eurobarometer. (2016). Gender-based violence, special Eurobarometer 449, European Commission. http://ec.europa.eu/COMMFron tOffice/publicopinion/index.cfm/Survey/getSurveyDetail/instru ments/SPECIAL/surveyKy/2115

Eurobarometer. (2017). Gender equality, Special Eurobarometer 465, European Commission. https://data.europa.eu/euodp/en/data/data set/S2154_87_4_465_ENG/resource/6flbfbdb-e015-4068-8e8af022a23c9497

European Union Agency for Fundamental Rights. (2014). Violence against women: An EU-wide issue. Publications Office of the European Union. https://fra.europa.eu/sites/default/files/fra_uploads/ fra-2014-vaw-survey-main-results-apr14_en.pdf

Eyssel, F., \& Bohner, G. (2011). Schema effects of rape myth acceptance on judgments of guilt and blame in rape cases: The role of perceived entitlement to judge. Journal of Interpersonal Violence, 26(8), 1579-1605.

Felson, R. B., \& Pare, P. P. (2005). The reporting of domestic violence and sexual assault by nonstrangers to the police. Journal of Marriage and Family, 67, 597-610.

Filipas, H. H., \& Ullman, S. E. (2001). Social reactions to sexual assault victims from various support sources. Violence \& Victims, 16, 673-692.

Fishbein, M., \& Ajzen, I. (2010). Predicting and changing behavior: The reasoned action approach. Taylor \& Francis.
Fisher, B. S., Cullen, F. T., \& Turner, M. G. (2000). The sexual victimization of college women. U.S. Department of Justice.

Fisher, B. S., Daigle, L. E., Cullen, F. T., \& Turner, M. E. (2003). Reporting sexual victimization to the police and others: Results from a national-level study of college women. Criminal Justice and Behavior, 30, 6-38.

Frazier, P. A., \& Haney, B. (1996). Sexual assault cases in the legal system: Police prosecutor and victim perspectives. Law and Human Behaviour, 20, 607-628.

Frese, B., Moya, M., \& Megías, J. L. (2004). Social perception of rape: How rape myth acceptance modulates the influence of situational factors. Journal of Interpersonal Violence, 19(2), 143-161.

Gregor, A., \& Kováts, E. (2018). Women's affairs 2018, societal problems and solution strategies in Hungary. Friedrich Ebert Stiftung. https://library.fes.de/pdf-files/bueros/budapest/14462.pdf

Gregor, A., \& Kováts, E. (2019). Work-life: Balance? Tensions between care and paid work in the lives of Hungarian women. Social Science Review, 7, 91-116.

Grubb, A., \& Turner, E. (2012). Attribution of blame in rape cases: A review of the impact of rape myth acceptance, gender role conformity and substance use on victim blaming. Aggression and Violent Behavior, 17(5), 443-452.

Grzebalska, W., Kováts, E., \& Pető, A. (2017, January 13). Gender as symbolic glue: How "gender" became an umbrella term for the rejection of the (neo)liberal order. Krytyka Polityczna \& European Alternatives. http://politicalcritique.org/long-read/2017/gender-assymbolic-glue-how-gender-became-an-umbrella-term-for-therejection-of-the-neoliberal-order/

Grzebalska, W., \& Pető, A. (2018, May-June). The gendered modus operandi of the illiberal transformation in Hungary and Poland. Women's Studies International Forum, 68, 164-172.

Gylys, J. A., \& McNamara, J. R. (1996). Acceptance of rape myths among prosecuting attorneys. Psychological Reports, 79, 15-18.

Hammond, E. M., Berry, M. A., \& Rodriguez, D. N. (2011). The influence on rape myth acceptance, sexual attitudes, and belief on a just world on attributions of responsibility in a date rape scenario. Legal and Criminological Psychology, 16(2), 242-252.

Hayes, R. M., Abbott, R. L., \& Cook, S. (2016). It's her fault: Student acceptance of rape myths on two college campuses. Violence Against Women, 22(13), 1540-1555.

Hayes, R. M., Lorenz, K., \& Bell, K. A. (2013). Victim blaming others: Rape myth acceptance and the just world belief. Feminist Criminology, 8(3), 202-220.

Heath, N. M., Lynch, S. M., Fritch, A. M., \& Wong, M. M. (2013). Rape myth acceptance impacts the reporting of rape to the police: A study of incarcerated women. Violence Against Women, 19(9), 1065-1078.

Herman, J. L. (2015). Trauma and recovery: The aftermath of violence-From domestic abuse to political terror. Hachette.

Hochschild, A. (2000). The nanny chain. The American Prospect, 11, $1-4$.

Human Rights Watch. (2020, November 18). Hungary: Intensified attack on LGBT people. Human Rights Watch. https:// www.hrw.org/news/2020/11/18/hungary-intensified-attack-lgbtpeople\# 
Inotai, E. (2019, August 6). Hungary's family plan seeks to "save the nation." Balkan Insight. https://balkaninsight.com/2019/08/06/hun garys-family-plan-seeks-to-save-the-nation/

Johnson, J. D., \& Russ, I. (1989). Effects of salience of consciousnessraising information on perception of acquaintance versus stranger rape. Journal of Applied Social Psychology, 19, 1182-1197.

Jordan, J. (2004). Beyond belief? Police, rape and women's credibility. Criminology and Criminal Justice, 4, 29-59.

Kilpatrick, D. G., Edmunds, C. N., \& Seymour, A. K. (1992). Rape in America: A report to the nation. National Victim Center and Medical University of South Carolina.

Kilpatrick, D. G., Resnick, H. S., Ruggiero, K. J., Conoscenti, L. M., \& McCauley, J. (2007). Drug-facilitated, incapacitated, and forcible rape: A national study. U.S. Department of Justice.

Kovács, Z. (2019, December 25). 2019: The year of Hungarian families. About Hungary. http://abouthungary.hu/blog/2019-the-yearof-hungarian-families/

Krahé, B. (1991). Police officers' definitions of rape: A prototype study. Journal of Community \& Applied Social Psychology, 1(3), 223-244.

Krahé, B., Temkin, J., Bieneck, S., \& Berger, A. (2008). Prospective lawyers' rape stereotypes and schematic decision making about rape cases. Psychology, Crime and Law, 14(5), 461-479.

Krekó, P., \& Enyedi, Z. s. (2018). Explaining Eastern Europe: Orban's laboratory of illiberalism. Journal of Democracy, 29(3), 39-51.

Littleton, H. L., Axsom, D., Breitkopf, C. R., \& Berenson, A. (2006). Rape acknowledgment and postassault experiences: How acknowledgement status relates to disclosure, coping, worldview, and reactions received from others. Violence and Victims, 21, 761-778.

Lonsway, K. A., \& Fitzgerald, L. F. (1994). Rape myths: In review. Psychology of Women Quarterly, 18, 133-164.

Lonsway, K. A., \& Fitzgerald, L. F. (1995). Attitudinal antecedents of rape myth acceptance: A theoretical and empirical reexamination. Journal of Personality and Social Psychology, 68, 704-711.

Lovett, J., \& Kelly, L. (2009). Different systems, similar outcomes? Tracking attrition in reported rape cases in eleven European countries. Child and Woman Abuse Studies Unit. http://www.cwa su.org/publication_display.asp?pageid $=$ PAPERS\&type $=1 \&$ pagekey $=44 \&$ year $=2009$

Lovett, J., Uzelac, G., \& Horváth, M. (2007). Rape in the 21st century: Old behaviors, new contexts and emerging patterns. ESRC End of Award Report (RES-000-22-1679). Economic and Social Research Council.

Nyúl, B., Kende, A., Engyel, M., \& Szabó, M. (2018). Perception of a perpetrator as a successful person predicts decreased moral judgment of a rape case and labeling it as rape. Frontiers in Psychology, 9, 2555. doi: 10.3389/fpsyg.2018.02555

Madigan, L., \& Gamble, N. (1991). The second rape: Society's continued betrayal of the victim. Lexington Books.

Maier, S.L. (2008). "I have heard horrible stories ...": Rape victim advocates' perceptions of the revictimization of rape victims by the police and medical system. Violence Against Women, 14(7), 786-808.

McClintock, A. (1993). Family feuds: Gender, nationalism and the family. Feminist Review, 44, 61-80.
McGregor, M. J., Wiebe, E., Marion, S. A., \& Livingstone, C. (2000). Why don't more women report sexual assault to the police? (Research letter). Canadian Medical Association Journal, 162, 659-662.

McMahon, S. (2010). Rape myth beliefs and bystander attitudes among incoming college students. Journal of American College Health, 59(1), 3-11.

Moore, B. M., \& Baker, T. (2018). An exploratory examination of college students' likelihood of reporting sexual assault to police and university officials: Results of a self-report survey. Journal of Interpersonal Violence, 33(22), 3419-3438.

Page, A. D. (2008). Judging women and defining crime: Police officers' attitudes toward women and rape. Sociological Spectrum, 28(4), 389-411.

Papp, R. K. (2018, February 2). \#MeToo in Hungary: Liberal selfcleansing or real change? Public Seminar. https://publicseminar. org/2018/02/metoo-in-hungary/

Parratt, K. A., \& Pina, A. (2017). From "real rape" to real justice: A systematic review of police officers' rape myth beliefs. Aggression and Violent Behavior 34, 68-83.

Parti, K., Szabó, J., \& Virág, G. y. (2016). A média azt üzente ... Szexuális erőszakkal kapcsolatos ismeretek, vélemények és attitüdök vizsgálata egy médiakampány kapcsán, [It was in the TV ... Knowledge, opinions, attitudes about rape myths following a media campaign]. Médiakutató, 16(2), 7-24.

Parti, K., Szabó, J., \& Virág, G. y. (2017a). A szexuális erőszak jellemzői egy aktakutatás tükrében [Characteristics of sexual violence in a criminal file based research]. In K. Parti (Ed.), Szexuális eröszak: Mitosz és valóság. Kutatások a szexuális eröszakról (pp. 159-200).Országos Kriminológiai Intézet.

Parti, K., Szabó, J., \& Virág, G. y. (2017b). Szexuális eröszak-OKRI kutatás egy bünmegelözési kampány kapcsán [Sexual violence-A research of NICH following a crime prevention campaign]. Kriminológiai Közlemények, 77, 129-153.

Patterson, D., \& Campbell, R. (2010). Why rape survivors participate in the criminal justice system. Journal of Community Psychology, $38,191-205$.

Paul, L. A., Zinzow, H. M., McCauley, J. L., Kilpatrick, D. G., \& Resnick, H. S. (2014). Does encouragement by others increase rape reporting? Findings from a national sample of Women. Psychology of Women Quarterly, 38(2), 222-232.

Payne, D. L., Lonsway, K. A., \& Fitzgerald, L. F. (1999). Rape myth acceptance: Exploration of its structure and its measurement using the Illinois Rape Myth Acceptance Scale. Journal of Research in Personality, 1(33), 27-68.

Peterson, Z. D., \& Muehlenhard, C. L. (2004). Was it rape? The function of women's rape myth acceptance and definitions of sex in labeling their own experiences. Sex Roles: A Journal of Research, 51, 129-144.

Petö, A. (2003). Memory and the narrative of rape in Budapest and Vienna in 1945. In R. Bessel \& D. Schumann (Eds.), Life after Death. Approaches to a cultural and social history of Europe during the 1940s and 1950s (pp. 129-148). Publications of the German Historical Institute. Cambridge University Press.

Pető, A. (2018). Elmondani az Elmondhatatlant. [To Tell the Unspeakable]. Jaffa. 
Petõ, A. (2019). Szexualitás és társadalmi tükrözõdése. A normaváltás nehézségei: a \#Metoo tanulságai [Sexuality and social reflection. Difficulties of norm changing: The case of \#Metoo]. Journal of History of Culture, Science and Medicine, 10(18), 147-151.

Pivarnyik, B. (2018, July 4). Family and gender in Orbán's Hungary. Heinich Böll Stiftung. https://www.boell.de/en/2018/07/04/familyand-gender-viktor-orbans-hungary

Robinson, R. A., \& Gadd, D. (2015). Annihilation anxiety and crime. Theoretical Criminology, 20(2), 185-204.

Russell, D. E. H., \& Bolen, R. M. (2000). The epidemic of rape and child sexual abuse in the United States. SAGE.

Sabina, C., \& Ho, L. Y. (2014). Campus and college victim responses to sexual assault and dating violence: Disclosure, service utilization, and service provision. Trauma, Violence, and Abuse, 15(3), 201-226.

Schuller, R., \& Stewart, A. (2000). Police responses to sexual assault complaints: The role of perpetrator/complainant intoxication. Law and Human Behavior, 24(5), 535-551.

Serhan, Y. (2017, June 13). Hungary's anti-foreign NGO law. The Atlantic. https://www.theatlantic.com/news/archive/2017/06/hun garys-anti-foreign-ngo-law/530121/

Serughetti, G. (2019, January 11). Why Orban's Hungary is afraid of Feminism and Academic Freedom (and George Soros, of course). Reset DOC: Dialogues on Civilizations.

Sleath, E., \& Bull, R. (2012). Comparing rape victim and perpetrator blaming in a police officer sample: Differences between police officers with and without special training. Criminal Justice and Behavior, 39, 642-661.

Smith, C. P., \& Freyd, J. J. (2013). Dangerous safe havens: Institutional betrayal exacerbates sexual trauma. Journal of Traumatic Stress, 26, 119-124.

Smith, C. P., \& Freyd, J. J. (2014). Institutional betrayal. American Psychologist, 69(6), 575-587.

Smith, O., \& Skinner, T. (2017). How rape myths are used and challenged in rape and sexual assault trials. Social \& Legal Studies, 26(4), 441-466.

Snyder, M., \& Miene, P. (1994). On the functions of stereotypes and prejudice. In M. P. Zanna \& J. M. Olson (Eds.), The psychology of prejudice: The Ontario symposium (pp. 33-54). Erlbaum.

Spohn, R., Bjornsen, A., \& Wright, E. M. (2017). Factors associated with reporting of sexual assault among college and non-college women. Journal of Aggression Conflict and Peace Research, 9(4), 279-289.

Staubli, S. (2017). Trusting the police: Comparisons across Eastern and Western Europe. (Kultur und soziale Praxis, Trans.). Transcript Verlag.

Stewart, A. L., \& Maddren, K. (1997). Police officers' judgement of blame in family violence: The impact of gender and alcohol. Sex Roles, 37, 921-934.

Suarez, E., \& Gadalla, T. M. (2010). Stop blaming the victim: A metaanalysis on rape myths. Journal of Interpersonal Violence, 25(11), 2010-2035.

Suzuki, Y. E., \& Bonner, H. S. (2017). Factors associated with college students' responses to rape-disclosure scenarios: Influence of gender, rape characteristics, and opinions about health care professionals. Journal of School Violence, 16(2), 160-172.

Symonds, M. ([1980] 2010). The "second injury" to victims of violent acts. The American Journal of Psychoanalysis, 70(1), 34-41.

Szécsi, N., \& Géra, E. (2015). A budapesti úrinő magánélete, 1860-1914 [The private life of a budapest lady, 1860-1914]. Európa.

Tarlea, S. (2017). Higher education governance in Central and Eastern Europe: A perspective on Hungary and Poland. European Educational Research Journal, 16(5), 670-683.

Temkin, J., Gray, J. M., \& Barrett, J. (2018). Different functions of rape myth use in court: Findings from a trial observation study. Feminist Criminology, 13(2), 205-226.

Temkin, J., \& Krahé, B. (2008). Sexual assault and the justice gap: A question of attitude. Hart Publications.

Timár, J. (2019). Hungarian feminist geography in a curved space? Gender, Place \& Culture, 26(7-9), 1094-1102.

Uhde, Z. (2016). From women's struggles to distorted emancipation: The interplay of care practices and global capitalism. International Feminist Journal of Politics, 18(3), 390-408.

Ullman, S. E. (1999). Social support and recovery from sexual assault: A review. Aggression and Violent Behavior: A Review Journal, 4, 343-358.

Ullman, S. E., Filipas, H. H., Towsend, S. M., \& Starzynski, L. L. (2007). Psychosocial correlates of PTSD symptom severity in sexual assault survivors. Journal of Traumatic Stress, 20, 821-831.

Venema, R. M. (2014). Police officer schema of sexual assault reports: Real rape, ambiguous cases, and false reports. Journal of Interpersonal Violence, 15(1), 25-44.

Vida, B. (2020). New waves of anti-sexual and reproductive health and rights strategies in the European Union: The anti-gender discourse in Hungary. Sexual and Reproductive Health Matters, 27(2), 13-16.

Virág, G. y. (2004). Sexual violence. In F. Irk (Ed.), Victims and Opinions, Part II (pp. 71-83). Országos Kriminológiai Intézet.

Walby, S. (2011). The future of feminism. Polity Press.

Wilson, M., \& Scholes, A. (2009). The typical rape: Factors affecting victims' decision to report. In J. Wood \& T. Gannon (Eds.), Public opinion and criminal justice (pp. 123-144). Willan.

Wirth, J., \& Winkler, Zs. (2015). Nők elleni eröszak az adatok tükrében. FRA-népesség-bünügyi statisztikák [Violence against women in light of data. FRA statistics of crime and population]. NANE. https://nokjoga.hu/sites/default/files/filefield/nane-franepesseg-enyubs-final-2014-w-w-2015jun19.pdf

Wolitzky-Taylor, K. B., Resnick, H. S., McCauley, J. L., Amstadter, A. B., Kilpatrick, D. G., \& Ruggiero, K. J. (2011). Is reporting of rape on the rise? A comparison of women with reported versus unreported rape experiences in the national women's study-replication. Journal of Interpersonal Violence, 26, $807-832$.

Yang, O. K. (2006). Family and new governance. Ewha Woman's University Press.

Zimanyi, E. (2020). Family borders: Hungary's campaign for the "Family Protection Action Plan." Feminist Media Studies, 20(2), 305-309. 


\section{Author Biographies}

Katalin Parti is an assistant professor of sociology at Virginia Polytechnic Institute and State University. As a Fulbright Research Scholar, she studies interpersonal cyber violence, gender, crime, and sexuality and is the Co-PI of the project Justice for Victims of Sexual Violence in Hungary.

Robin A. Robinson is a professor emerita of sociology at the University of Massachusetts Dartmouth, a resident scholar at Brandeis University Women's Studies Research Center, and a research fellow at the University of Glasgow Scottish Centre for Crime and Justice Research. As a Fulbright Research Scholar, she studies trauma, gender, and crime and is the Co-PI of the project Justice for Victims of Sexual Violence in Hungary.

David Kohlmann is a $\mathrm{PhD}$ candidate in Eötvös Loránd University Doctoral School of Sociology in Budapest. His research focuses on the use of attitude measures in nonresearch interventions aiming to change social attitudes. He is interested in the application of scientifically valid measurement methods in circumstances not ideal for social science research. He is a research assistant of the project Justice for Victims of Sexual Violence in Hungary.

Enikö Virágh is a PhD candidate in Eötvös Loránd University Doctoral School of Sociology in Budapest. Her research focuses on the role of media in preserving victim blaming and rape myth acceptance. She is a research assistant of the project Justice for Victims of Sexual Violence in Hungary.

Dóra Varga-Sabján is a psychologist and $\mathrm{PhD}$ candidate at the Faculty of Law, University of Pécs. Her research focuses on the behavioral and emotional consequences of child abuse and the institutional responses to the phenomenon. She is interested in disseminating a trauma-informed approach to institutions working with neglected and abused children and youth. She is a research assistant of the project Justice for Victims of Sexual Violence in Hungary. 